\title{
Effect of fenugreek (Trigonella foenum-graecum) on experimentally induced diabetes mellitus in male rabbits
}

\author{
Nadia Abdulkarim Salih \\ Coll. of Vet. Med./Univ. of Sulaimani \\ email: nadiasalih9@gmail.com
}

(Received 4 June 2013, Accepted 18 November 2013 )

\begin{abstract}
The study was conducted to investigate the effect of orally administered fenugreek on some biochemical parameters in diabetic male rabbits experimentally induced by intra peritoneal injection of alloxan monohydrate $75 \mathrm{mg} / \mathrm{kg}$. Twenty five male local breed rabbits were divided into 5 equal groups; G1 normal control group, G2 diabetic non-herb treated, G3 normal rabbit treated with the herb. While, each of G4 and G5 were diabetic rabbits treated with 2 and $3 \mathrm{~g}$ /day single oral dose of fenugreek for 30 consecutive days respectively. Blood sample were taken at zero day, 2 weeks and 4 weeks for estimation of serum glucose, cholesterol, triglyceride, ALT, and AST. At the end of the experiment, animals were sacrificed in order to prepare liver tissue homogenate to calculate the level of Malondialdehyde (MDA) and glutathione (GSH) to explore the role of fenugreek as antioxidant herb. Results were revealed an increase in serum glucose, cholesterol, triglyceride, ALT, AST, and MDA level and reduced glutathione level in G2. While, oral administration of fenugreek showed a significant reduction in total lipids and serum sugar in diabetic rabbits and have no any adverse effect on the main parameters of the body, the herb play a great role as antioxidant factor as indicated by increasing GSH level and reduce MDA level.
\end{abstract}

Key words: Fenugreek, diabetes, cholesterol, triglyceride, ALT, AST, MDA, GSH.

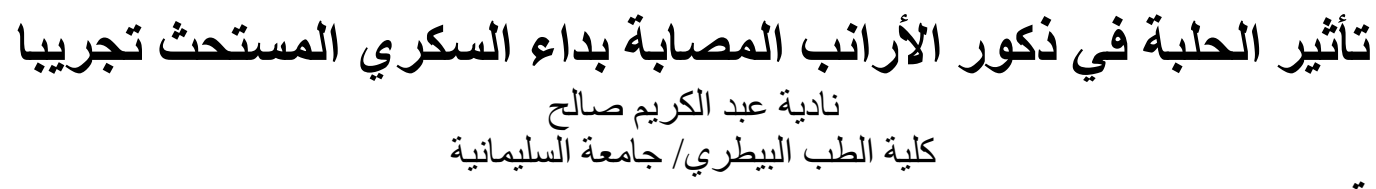

الخلاصة

هدفت الدراسة الى معرفة تأثثر الحلبة على بعض المقاييس الكيميائية الحياتية في ذكور الأر انب المصابة بداء السيكاء السكري

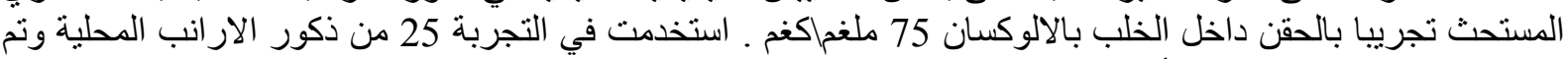

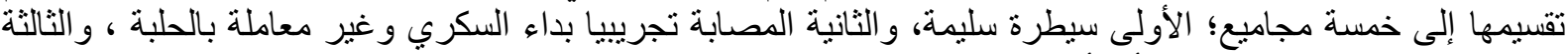

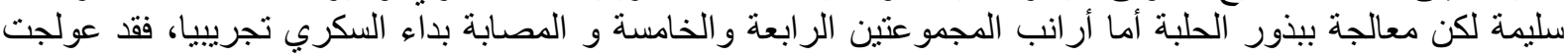

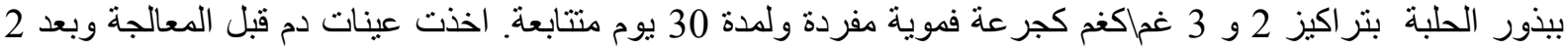

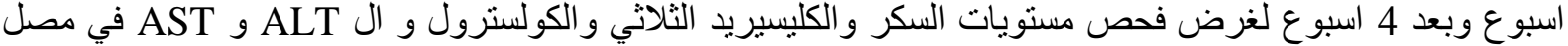

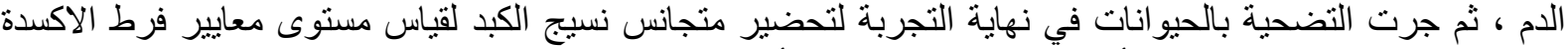

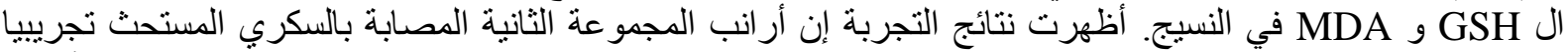

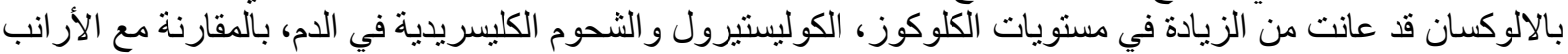

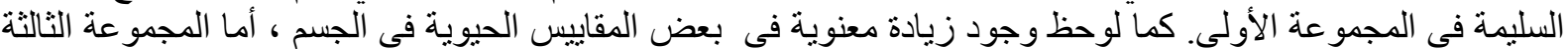

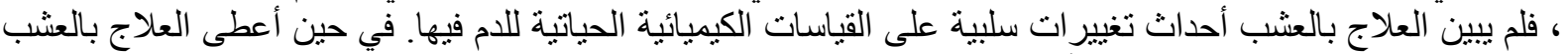

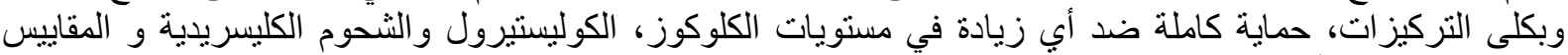

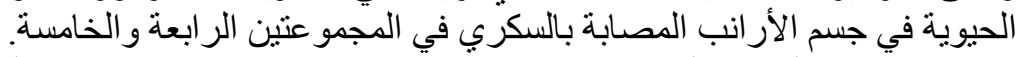
الكلمات المفتاحية: الحلبة ، داء السكري ، الكولسترول ، الثحوم الكليسريدية.

\section{Introduction}

Fenugreek is one of the oldest known herbs, originating in Europe and Asia but now grown worldwide. Historically, fenugreek was used for a variety of health conditions, including menopausal symptoms and digestive problems. It was also used for inducing childbirth, and to stimulate milk production in breast feeding women $(1,2,3)$. 
The plant seeds contain medicinal properties called glycosidal saponins: diosgenin, yamogenin, tigogenin, and neotigogenin, the saponins can produce steroidal effects that could reduce inflammation in the body. The other active ingredient found in fenugreek is 4-hydroxyisoleucine $(4,5)$. Fenugreek seeds are a rich source of the polysaccharide galactomannan. They are also a source of saponins such as diosgenin, yamogenin, gitogenin, tigogenin, and neotigogens. Flavonoids, amino acid and alkaloids, other bioactive constituents of fenugreek include mucilage, volatile oils, these constituents seem to work in a synergistic way to produce health effects (6). Fenugreek powder is rich in nutrients like vitamin $\mathrm{E}$, vitamin $\mathrm{A}$, vitamin $\mathrm{B} 1$ and vitamin $\mathrm{C}$. The product is inexpensive, readily available and can be used in a variety of ways $(7,8)$

\section{Materials and methods}

Animals: Twenty five physically healthy male local breed domestic rabbits aged 6-7 months and weighing 1.6-1.7 $\mathrm{kg}$ were utilized. Rabbits were adapted preexperimentally for one week, by allocating two rabbits per housing cage and were given food (barely and vegetables) and tap water during the experimental period.

Preparation of the fenugreek: Fenugreek seeds were obtained from local market in Sulaimani. Seeds were washed in distilled water, and milled to a fine powder in a mixer then mixed with worm water in order to prepare a solution ready for oral administration by gavage tube.

Blood sampling: Blood samples were collected from the rabbit's marginal ear vein 3 times, at zero day, 2 weeks and 4 weeks post treatment (PT), centrifuged at 3000 round per minutes for ten minutes. Serums were collected in clean test tubes (9). Different tests were analyzed by using LISA 200 (Pejohesh - co., France). All kits that are specifically work on LISA 200 were purchased from (Pars company-Iran). LISA 200 is an auto analyzer which enables handling of a wide range of analyses of biochemical assays of substrates, enzymes and electrolytes. At the end of the experiment after 30 days, animals were sacrificed by anesthetic ether in order to prepare liver tissue homogenate.

Preparation of tissue homogenate: After sacrificed, livers were quickly excised, placed in chilled phosphate buffer solution ( $\mathrm{pH}$ 7.4) at $4^{\circ} \mathrm{C}$, blotted with filter paper and weighed. One gram of liver was then taken to prepare $10 \%$ tissue homogenate using the same buffer solution utilizing tissue homogenizer (10) at set 3 for 1 minute at $4{ }^{\circ} \mathrm{C}$.

\section{Measurement of lipid peroxidation:}

Malondialdehyde (MDA) the end product of lipid peroxidation, was analyzed according to the method of Buege and Aust (11), which is based on the reaction of MDA with thiobarbituric acid (TBA) to form MDA-TBA complex, a red chromophore, which can be quantitated spectrophotometrically (12).

\section{Determination of glutathione level:}

Total thiol groups contents, which can be used as indicator for reduced glutathione (GSH), was determined according to the method of Ellman (3).

Statistical analysis: Data are expressed as mean \pm Standard error $(\mathrm{M} \pm \mathrm{SE})$, where a significant interaction between major factors was identified by ANOVA SPSS version 10.0. Duncan's new multiple range tests were used post - ANOVA to identify significant differences between mean values at $(\mathrm{p}<$ 0.05) (13).

Induction of diabetes mellitus: Animals were fasted for $12 \mathrm{~h}$ they allowed access to the water before induction of diabetes. Intraperitoneal administration of Alloxan monohydrate (Sigma) for 2 days which was freshly prepared AXN (75 $\mathrm{mg} / \mathrm{kg}$ in $0.9 \%$ sodium chloride) at dose of $75 \mathrm{mg} / \mathrm{kg} /$ day after estimation of blood glucose level those animals that have over $200 \mathrm{mg} / \mathrm{dl}$ serum glucose they were considered diabetic and used for the further experiment, Since alloxan is capable of producing fatal hypoglycemia, animals were treated with $20 \%$ glucose solution intraperitoneally after 6 $\mathrm{h}$ from alloxan injection $(14,15)$.

\section{Experimental design:}

Group 1 (control group); the rabbits were treated by one $\mathrm{ml}$ of distilled water (D.W.), once orally for 30 consecutive days. Group 2 
(diabetic group); diabetic mellitus was induced experimentally by treatment with a two doses of alloxan monohydrate $(75 \mathrm{mg} / \mathrm{kg})$, administered intraperitoneally. Group 3; these were normal rabbits, but fed orally with the herb (fenugreek), at dose $2 \mathrm{~g} / \mathrm{kg}$ by gavage tube for 30 consecutive days. Group 4 and Group 5; the rabbits in both these groups were suffering from diabetic mellitus, were treated for 30 consecutive days with a daily single oral dose of fenugreek $2 \mathrm{~g} /$ day, and $3 \mathrm{~g} /$ day respectively, by gavage tube.

\section{Results}

The serum glucose, cholesterol, AST, ALT, and triglyceride levels in G2 was significantly increased at 2 nd and 4 th weeks of experiment in compare with the pretreatment reading and G1 normal control group reading. Treatment of $2 \mathrm{~g} / \mathrm{kg}$ of fenugreek to the non-diabetic rabbits in G3 show a non-significant changes of serum glucose, cholesterol, AST, ALT, and triglyceride levels, and the reading remains like the pretreatment reading and control group reading. The two doses 2 and $3 \mathrm{~g} / \mathrm{kg}$ of fenugreek used in G4 and G5 diabetic rabbits at 2 nd and 4th weeks declare an stable level of serum glucose, cholesterol, AST, ALT, and triglyceride which remain resemble that of the pretreatment reading and control group reading (Tables 1, 2, 3, 4, and 5). Once orally treatment of rabbits with fenugreek for consecutive 30-days resulted in decline in hepatic MDA contents as seen in G4 and G5 in compare with G2 diabetic non-treated rabbits. While the level of GSH was significantly higher in G4 and G5 (Table 6). In each table the values are expressed as mean $\pm \mathrm{SE}$; No. of rabbits /groups $=5$, $(\mathrm{a}$, b, c, d) Values within columns with no common superscripts differ significantly $(\mathrm{p} \leq \mathbf{0 . 0 5})$.

Table (1): Effects of fenugreek treatment on serum glucose levels (mg/dl) in different experimental groups and periods.

\begin{tabular}{|c|c|c|c|c|}
\hline Groups & Treatment & Pretreatment & $2^{\text {nd }}$ week & $4^{\text {th }}$ week \\
\hline G1 & Control (non-diabetic rabbits) & $99.23 \pm 1.9 \mathrm{a}$ & $99.91 \pm 1.324 \mathrm{a}$ & $98.4 \pm 1.7 \mathrm{a}$ \\
\hline G2 & Alloxan75 mg/kg(diabetic rabbits non-treated) & $99.3 \pm 0.11 \mathrm{a}$ & $252.31 \pm 1.12 \mathrm{~b}$ & $263 \pm 1.88 \mathrm{~b}$ \\
\hline G3 & Fenugreek 2 g/kg (non-diabetic rabbits) & $98.65 \pm 0.99 \mathrm{a}$ & $97.2 \pm 0.87 \mathrm{a}$ & $97.4 \pm 0.74 \mathrm{a}$ \\
\hline G4 & Fenugreek 2 g/kg /diabetic rabbits & $99.7 \pm 0.991 \mathrm{a}$ & $98.5 \pm 0.186 \mathrm{a}$ & $98.8 \pm 1.67 \mathrm{a}$ \\
\hline G5 & Fenugreek 3 g/kg /diabetic rabbits & $99.7 \pm 0.89 \mathrm{a}$ & $98.5 \pm 0.91 \mathrm{a}$ & $97.1 \pm 0.89 \mathrm{a}$ \\
\hline
\end{tabular}

Table (2):- Effects of fenugreek treatment on serum cholesterol levels (mg/dl) in different experimental groups and periods.

\begin{tabular}{|c|c|c|c|c|}
\hline Groups & Treatment & Pretreatment & $2^{\text {nd }}$ week & $4^{\text {th }}$ week \\
\hline G1 & Control (non-diabetic rabbits) & $97.65 \pm 1.21 \mathrm{a}$ & $96.11 \pm 1.24 \mathrm{a}$ & $96.59 \pm 0.68 \mathrm{a}$ \\
\hline G2 & Alloxan75 mg/kg(diabetic rabbits non-treated) & $95.13 \pm 0.43 \mathrm{a}$ & $230.31 \pm 1.32 \mathrm{~b}$ & $330 \pm 3.1 \mathrm{~b}$ \\
\hline G3 & Fenugreek 2 g/kg (non-diabetic rabbits) & $95.13 \pm 1.1 \mathrm{a}$ & $93.2 \pm 0.16 \mathrm{a}$ & $92.4 \pm 0.74 \mathrm{a}$ \\
\hline G4 & Fenugreek 2 g/kg /diabetic rabbits & $96.7 \pm 0.76 \mathrm{a}$ & $96.84 \pm 0.86 \mathrm{a}$ & $95.9 \pm 1.56 \mathrm{a}$ \\
\hline G5 & Fenugreek 3 g/kg /diabetic rabbits & $96.13 \pm 1.1 \mathrm{a}$ & $96.13 \pm 1.1 \mathrm{a}$ & $94.13 \pm 1.1 \mathrm{a}$ \\
\hline
\end{tabular}

Table (3). Effect of fenugreek treatment on serum aspartate amino transferase levels $(\mathrm{mg} / \mathrm{dl})$ in different experimental groups and periods

\begin{tabular}{|c|c|c|c|c|}
\hline Groups & Treatment & Pretreatment & $2^{\text {nd }}$ week & $4^{\text {th }}$ week \\
\hline G1 & Control (non-diabetic rabbits) & $250.20 \pm 1.1 \mathrm{a}$ & $251.22 \pm 0.82 \mathrm{a}$ & $251.7 \pm 1.1 \mathrm{a}$ \\
\hline G2 & Alloxan75 mg/kg (diabetic rabbits non-treated) & $251.20 \pm 1.1 \mathrm{a}$ & $269.14 \pm 0.66 \mathrm{~b}$ & $274.14 \pm 0.56 \mathrm{~b}$ \\
\hline G3 & Fenugreek 2 g/kg (non-diabetic rabbits) & $252 \pm 0.99 \mathrm{a}$ & $250.78 \pm 0.91 \mathrm{a}$ & $250.44 \pm 0.98 \mathrm{a}$ \\
\hline G4 & Fenugreek 2 g/kg /diabetic rabbits & $252.67 \pm 1.11 \mathrm{a}$ & $252.52 \pm 1.32 \mathrm{a}$ & $251.50 \pm 1.87 \mathrm{a}$ \\
\hline G5 & Fenugreek 3 g/kg/diabetic rabbits & $255.67 \pm 1.11 \mathrm{a}$ & $253.50 \pm 1.87 \mathrm{a}$ & $252.67 \pm 2.1 \mathrm{a}$ \\
\hline
\end{tabular}


Table (4): Effect of fenugreek treatment on serum alanine aminotransferase levels $(\mathrm{mg} / \mathrm{dl})$ in different experimental groups and periods.

\begin{tabular}{|c|c|c|c|c|}
\hline Groups & Treatment & Pretreatment & $2^{\text {nd }}$ week & $4^{\text {th }}$ week \\
\hline G1 & Control (non-diabetic rabbits) & $136.30 \pm 1.1 \mathrm{a}$ & $135.9 \pm 1.5 \mathrm{a}$ & $137.21 \pm 0.9 \mathrm{a}$ \\
\hline G2 & Alloxan75 mg/kg (diabetic rabbits non-treated) & $134 \pm 0.91 \mathrm{a}$ & $169.54 \pm 1.56 \mathrm{~b}$ & $173.44 \pm 0.56 \mathrm{~b}$ \\
\hline G3 & Fenugreek 2 g/kg (non-diabetic rabbits) & $134.22 \pm 1.67 \mathrm{a}$ & $135.78 \pm 1.1 \mathrm{a}$ & $134.13 \pm 0.32 \mathrm{a}$ \\
\hline G4 & Fenugreek 2 $\mathrm{g} / \mathrm{kg} /$ diabetic rabbits & $135.33 \pm 0.69 \mathrm{a}$ & $134.39 \pm 0.99 \mathrm{a}$ & $133.90 \pm 0.39 \mathrm{a}$ \\
\hline G5 & Fenugreek $3 \mathrm{~g} / \mathrm{kg} /$ diabetic rabbits & $137.17 \pm 0.92 \mathrm{a}$ & $136.52 \pm 1.32 \mathrm{a}$ & $136 \pm 0.987 \mathrm{a}$ \\
\hline
\end{tabular}

Table (5) Effect of fenugreek treatment on serum triglyceride levels $(\mathrm{mg} / 100 \mathrm{ml})$ in different experimental groups and periods.

\begin{tabular}{|c|c|c|c|c|}
\hline Groups & Treatment & Pretreatment & $2^{\text {nd }}$ week & $4^{\text {th }}$ week \\
\hline G1 & Control (non-diabetic rabbits) & $90.26 \pm 1.6 \mathrm{a}$ & $90.11 \pm 0.53 \mathrm{a}$ & $91.63 .31 \pm 0.72 \mathrm{a}$ \\
\hline G2 & Alloxan75 mg/kg (diabetic rabbits non-treated) & $91.2 \pm 0.81 \mathrm{a}$ & $143 \pm 1.1 \mathrm{~b}$ & $159.14 \pm 1.2 \mathrm{~b}$ \\
\hline G3 & Fenugreek 2 g/kg (non-diabetic rabbits) & $91.4 . \pm 0.32 \mathrm{a}$ & $90.10 \pm 0.1 \mathrm{a}$ & $90.83 \pm 0.76 \mathrm{a}$ \\
\hline G4 & Fenugreek 2 g/kg /diabetic rabbits & $91.30 \pm 0.61 \mathrm{a}$ & $91 \pm 0.91 \mathrm{a}$ & $91.20 \pm 1.8 \mathrm{a}$ \\
\hline G5 & Fenugreek $3 \mathrm{~g} / \mathrm{kg} /$ diabetic rabbits & $90.47 \pm 1.9 \mathrm{a}$ & $90.52 \pm 1.1 \mathrm{a}$ & $90.50 \pm 0.87 \mathrm{a}$ \\
\hline
\end{tabular}

Table (6) Effect of fenugreek on liver tissue malondialdehyde (MDA) and glutathione (GSH) levels in experimental animal models.

\begin{tabular}{|c|c|c|c|}
\hline Groups & Treatment & MDA nmol $/ \mathrm{g}$ tissue & GSH $\mu \mathrm{mol} / \mathrm{g}$ tissue \\
\hline G1 & Control (non-diabetic rabbits) & $230.0 \pm 0.99 \mathrm{a}$ & $17.0 \pm 0.75 \mathrm{a}$ \\
\hline G2 & Alloxan75 mg $/ \mathrm{kg}($ diabetic rabbits non-treated) & $450.0 \pm 0.998 \mathrm{~d}$ & $12.5 \pm 0.81 \mathrm{a}$ \\
\hline G3 & Fenugreek 2 g/kg (non-diabetic rabbits) & $210.0 \pm 0.99 \mathrm{~b}$ & $27.3 \pm 0.8 \mathrm{~b}$ \\
\hline G4 & Fenugreek $2 \mathrm{~g} / \mathrm{kg} /$ diabetic rabbits & $306.0 \pm 1.0 \mathrm{c}$ & $35.0 \pm 1.0 \mathrm{c}$ \\
\hline G5 & Fenugreek $3 \mathrm{~g} / \mathrm{kg} /$ diabetic rabbits & $300.0 \pm 1.0 \mathrm{c}$ & $37.5 \pm 1.2 \mathrm{c}$ \\
\hline
\end{tabular}

Values with non-identical superscripts $(\mathbf{a}, \mathbf{b}, \mathbf{c}, \mathbf{d})$ are considered significantly different within the parameter $(\mathbf{P}<0.05)$

\section{Discussion}

The antidiabetic, antihyperlipidemic and antioxidant activities of fenugreek seeds were examined in this study. The finding of this study supports that reported by Sharma 1986, about the hypoglycemic effect of fenugreek in diabetic rats (16). Also Studies by (17) indicates that soluble dietary fraction of fenugreek seeds exerts anti-diabetic effects mediated through inhibition of carbohydrate digestion and absorption, and enhancement of peripheral insulin action. Fenugreek is used as a spice, vegetable and a medicinal plant. Since antioxidant properties have been linked to health benefits of natural products. Substances that are rich in antioxidants, like Fenugreek powder, can help the body fight off diseases and protect it (18) and (19).Fenugreek seeds exhibited the highest antioxidant activity compared with other fractions, because of the highest quantity of phenolic and flavonoid compounds that can be related to antioxidant activity, a study done by. (20) and (21) reveals significant antioxidant activity in germinated fenugreek seeds. Lipid peroxidation has been shown to be of great importance in mammalian physiology and pathophysiology. Increasing lipid peroxidation is generally believed to be an important underlying cause for initiation oxidative stress related various tissue injuries, cell death, and the progression of many acute and chronic diseases (22). Peroxidative degradation of membrane lipids of endoplasmic reticulum rich in polyunsaturated fatty acids leads to the formation of lipid peroxides, these in turn give products like MDA that cause damage to the membrane (5) and alter cellular function (23).Plants may act on blood glucose through different mechanisms, some of them may have insulin-like substances (24) some may inhibit insulin's activity $(6,7)_{2}$ and others may increase beta cells in the pancreas by activating regeneration of these cells.(3). Animals treated with alloxan showed a highly 
significant increase in MDA contents of liver tissue homogenate, compared to control (saline treated). Treatment of rabbits orally with once doses of fenugreek for 30 -days resulted in decline in hepatic MDA contents. The statistical reduction in the values of serum sugar, serum cholesterol, serum triglycerides, ALT, AST one month after treatment with fenugreek was thought to be due to its effect on body cells particularly those sensitive to absence or reduction of insulin levels. The reduction in above values confirmed both toxic effect of alloxan and the protective effect of fenugreek on the most important body tissues and organs. Fenugreek seeds have shown to have hypoglycemic and hypocholesterolemic effects on type 1 \& type 2 diabetes mellitus patients and experimental diabetic animals. Supplementation of fenugreek leaves lowers the lipid-profile in diabetes mellitus $(1,24)$.It is important to mention that the effect of fenugreek at dose $3 \mathrm{gram} / \mathrm{kg}$ was much better than fenugreek at dose 2 gram $/ \mathrm{kg}$ concerning the effect on GSH level, fenugreek is well absorbed when given orally and lead to significant increase in fenugreek level in blood and liver to reach a maximum after one or two hours. Fecal bile acid and cholesterol

\section{References}

1-Abdel-barry JA, Abdel-hassan IA, and Al-hakiem MH (1997). Hypoglycemic and antihyperglycemic effects of Trigonella foenum-graecum leaf in normal and alloxan induced diabetic rats. $\mathrm{J}$. Ethnopharmacol. ,58:149-155.

2-Asmena M, Alauddin M, Atiar R and Kabir A.(2009). Antihyperglycemic Effect of Trigonella Foenum-Graecum (Test on the Extract,Volume: 6, Issue: 3, Publisher: African Networks on Ethnomedicines, Pp: 255-261.

3-Ellman GL.(1960). Tissue sulfhydryl groups., Arch. Bio. Chem. Phys.,82(1):70-77.

4-Acharya S N, Srichamoren A, Basu S, Ooraikul B and Basu T.(2006). Improvement in the nutraceutical properties of fenugreek (Trigonella foenum-graecum L.) Songklanakarin J. Sci. Technol. 28(1): 1-9.

5-Bhattacharya D , Pandits R, Das N and Sur TK.(2003). Hepatoprotective effect of Himoliv® , a ploy herbal formation in rats. Ind. J. Physiol. Pharmacol.,47(3):435-440.

6-Bhide MB and Aiman R. (1979).Mechanism of action of oral antidiabetic drugs. Indian. J. Med. Res.,51:733. excretion are increased by fenugreek administration. This may be secondary to a reaction between the bile acids and fenugreek-derived saponins causing the formation of micelles too large for the digestive tract to absorb. Another hypothesis attributes the cholesterol lowering activities to the fiber-rich gum portion of the seed that reduces the rate of hepatic synthesis of cholesterol. It is likely that both mechanisms contribute to the overall effect.(9,15). A study has demonstrated the potent antioxidant properties of the fenugreek seeds by evaluation the protective effect of polyphenol-rich extract from the seeds of fenugreek against hydrogen peroxide(H202)induced oxidation in normal and diabetic human erythrocytes (RBCs).(15,17). The present study showed that fenugreek in different doses can give complete protection in diabetic rabbits and showed an obvious antioxidant effect which could help health status in normal and diabetic patients our results come in agreement with the results of other studies done by other researchers. The Fenugreek supplementation significantly lowered lipid peroxidation and significantly increased antioxidant system in diabetic rats in research study $(19,21)$

7-Buege JA and Aust SD.(1978).Microsomal lipid peroxidationb. Methods Enzymol.,(52):302-310.

8-Collier E, Watkinson A, Cleland $\mathrm{C}$ and Roth J.(1987). Partial purification and characterization of an insulin-like material from spinach and lemna gibba G3. J. Biol. Chem.,262:6238-47.

9-Laber-Laired K L, Swindle $M$ and Flechell P.(1996). Handbook of rodent and rabbit medicine. Pergamon veterinary handbook series. 1st Ed.pp.146-154.

10-Cotran RS, Kumar V and Robbins SL.(1994). Cell injury and cellular death. In: Robbins pathologic basis of disease, 5th Edition ,Prism Book PVTLtd.379-430.

11-Gopith k, Shanmugasundaram R, Radha S and Rajendran M. (1990). Possible regeneration of the islets of Langerhans in streptozotocin-diabetic rats given gymnema sylvestere leaf extract. J. Ethnopharm.,30:265-9.

12-Dixit P, Ghaskadbi S, Mohan H and Devasagayam T P. (2005). Antioxidant properties of germinated fenugreek seeds. Phytotherapy Research, 19: 977983. 
13-Halliwell B and Gutteridge J.(1999). Free radicals in biology and medicine. Oxford University press.Newyork.p:113-115

14-Jelodar GA and Nazifi S.(1998).Effect of onion, garlic and fenugreek on serum biochemical parameter of diabetic rats. Sci. J. Vet. Med. Ahwaz. Univ.,1:77-85.

15-Joanne B, Linda A and Philipson J D.(2002).Herbal medicines. (Second edition), published by pharmaceutical press (publication division of the Royal pharmaceutical society of Great Britain .p:204-210.

16-Sharma RD and Raghuram TC. (1988).Effect of fenugreek seeds on blood glucose and serum lipids in type I diabetes. Europ. J. Clin. Nutr. ,44:301-9.

17-Kaur C and Kapoor H C. (2002). Anti-oxidant activity and total phenolic content of some Asian vegetables. International Journal of Food Science \& Technology, 37: 153-161.

18-Szkudelski T. (2001). The mechanism of alloxan and streptozotocin action $B$ cells of the rat pancreas. Physiology Res., 50:536-546.

19-Toppo FA, Akhand R and Pathak AK. (2009). Pharmacological actions and potential uses of
Trigonella foenum-graecum: A review. Asian J. Pharm., Clin Res., 2: 29-38.

20-Nelson RW, Ihle S L, Lewis LD and Salisbury SK.(1991). Effects of dietary fiber supplementation on glycemic control in dogs with alloxan-induced diabetes mellitus. Am. J. Vet. Res.,52:60-66.

21-Xue WL, Zhang J and Wang ZL. (2007). Effect of Trigonella foenum-graecum (fenugreek) extract on blood glucose, blood lipid and hemorheological properties in streptozotocin-induced diabetic rats. Asia Pac. J. Clin. Nutr., 1:422-426.

22-Madar Z, Abel R, Samish S and Arad J.(1988). Glucose- lowering effect of fenugreek in NIDDM. Europ. J. Clin. Nutr.,42:51-4.

23-Maleppillil V, Sandeep S, Rishi R C and Manoj K B. (2005).The Fenugreek Seed Extract in AlloxanInduced Diabetic Rats and Its Use in Diabetes Mellitus: A Brief Qualitative Phytochemical and Acute Toxicity .Br. J. Pharmacol., 146(1): 41-48.

24-Srinivasan K. (2005). Plant foods in the management of diabetes mellitus: Spices as beneficial antidiabetic food adjuncts, 56( 6): 399414. 